\title{
The Place and Functions of the Figure of the Prophet in Turkish School Textbooks and General Religious Teaching
}

\author{
Citizenship Models and the Legitimisation of the State
}

\author{
Dilek Sarmis
}

The involvement of the Turkish state in religious teaching has a complex history, shaped by its particular relationship with secularism. The foundation of the Turkish Republic was based on a transfer of the prerogatives of şeyhülislam to the institutions of the new republican state, as part of a movement towards institutional secularisation, understood as a transfer to the state of authority over religious affairs. Religious education in public primary and secondary schools already existed at the end of the Ottoman Empire, and was maintained when the Turkish Republic was founded in 1923, but its extent varied in the subsequent decades. By the beginning of the 193os religious instruction had almost disappeared from public schools, but its rehabilitation began at the end of the 1940s, brought about by politicians who used the importance of religion in national culture and its benefits in the forming of citizens to justify its gradual return; its indirect status as an Islamic reference point in the general education system fits in with the nationalistic politics of the Turkish state during and since the 1940s. In recent years, as a result of a movement that began during the early $198 \mathrm{os}$, courses in religious culture have become generalised throughout public education, both primary and secondary. In this context the place occupied by the Prophet in the disciplines concerned relates not only to his centrality as messenger, historic figure, and receiver of the revelation, but to concepts of republican citizenship.

There is an established and developing literature on the teaching of religion in Turkish schools in general and in contemporary faculties of theology in particular, but some of the changes that have occurred in the last forty years cast a new light on those (nearly) real-time analyses of Turkish secularisation. In this complex history, the centrality of the Prophet remains constant, although it is not always obvious. The authors, theologians, and intellectuals of the republican period maintained their interest in this figure, approached in their writings through the universality of his words and his double nature 
as a human being who is also a messenger of God, of the divine, for all other humans. However, specific studies have not yet been dedicated to the place and role of the Prophetic figure in Turkey's public education, and it is certainly possible to ask questions about the manner in which the educational policies of the Turkish state exploit the Prophetic figure, and affect its treatment.

One of the difficulties facing researchers in this field lies in the relative invisibility of the figure of the Prophet in the historiography of religious teaching in republican Turkey. This historiography tends to concentrate on whether the religious education courses offered are optional, supererogatory, or obligatory, and on how such courses are structured in terms of content, timing, evaluation, and curriculum. What is more, the diverse nature of the educational institutions and universities whose courses touch on the figure of the Prophet blurs the overall analysis, because these may be institutions of general public education, or of professional public education (imam hatip, schools for imams), or faculties of theology (ilâhiyat fakülteleri); their functions and aims do not coincide.

Even within the framework of general public education we are confronted by a fairly varied menu of dedicated disciplines, with courses in the history of Islam (islâm tarihi dersi) alongside courses in religious morals and culture (Din Kültürü ve Ahlâk Bilgisi or DKAB); the distinctions between and respective limits of these courses are often unclear. Recently (and this is unprecedented in the history of the Turkish Republic), a programme of courses on the life of "our" Prophet has been inaugurated (Peygamberimizin Hayatı Dersi); this re-establishes the disciplinary autonomy of the siyer-i nebi courses that were an important part of religious teaching in Ottoman medrese and faculties of religious theology. Each of these didactic projects is made up of sequences that give details of different historical and doctrinal aspects of religious culture, especially biographical information on the life of the Prophet and information that is implicitly edifying because of his status as a model. Sequences devoted to the Prophet generally relate to courses on the history of Islam, and Muhammad is treated as a historical and identificatory figure, not as a doctrinal one.

In this chapter we will limit ourselves to general public education and the place of the Prophet therein. The teaching that takes place in structures that are exclusively devoted to religious education (schools for imams and theological faculties) exists within a different framework because of their scientifically and didactically more specific missions and the fact that they are oriented towards professional training: in these instances, the mastering of knowledge on the Prophet is pursued with different aims, in particular that of religious expertise. Nevertheless, we will examine aspects of the history of 
such structures; this allows us to contextualise the dynamics of courses on religion within general public education. The logic underpinning the integration of the figure of the Prophet into the Turkish republican national project can, in fact, be understood through the contents of this public teaching, and here it is possible to distinguish three major turning points in the programmes: 1948-49, around 1982-83, and since 2000. The sources on which we drew for this chapter are mainly textbooks, pedagogical programmes, and the texts of laws relating to public education in Turkey (Din dersi, DKAB, Peygamberimizin Hayatı).

Overall, these courses, laws, and programmes emphasise the historicity, humanity, simplicity, and exemplary nature of the Prophet, his life, and its continuing relevance to democratic and republican modernity. However, recently some modifications have been implemented, relating to the legitimisation of commemorations and of the cult of the Prophet, and to a form of autonomisation of religious knowledge (particularly around the sira); during previous decades these notions had become fragmented and diluted as a result of the national republican project.

\subsection{Republic and Religion: The Prophet as an Invisible Third Party}

We cannot separate the figure of the Prophet and its function in Turkish public education from the political and republican history of Turkish Islam, including state interventionism, as sanctioned by reforms and constitutional choices since 1942 that have had an impact on religion and the teaching of religion. The defeat of the sultan's imperial regime in 1918 led to the occupation of Istanbul by foreign powers and to a war of liberation directed by Mustafa Kemal (subsequently Atatürk), and eventually to the Treaty of Lausanne of 23 July 1923 and the proclamation of the new Turkish Republic on 29 October 1923. This new state instituted a series of reforms that equated revolutionary modernity with state management of religion: the abolition of the caliphate in 1924; the outlawing of the Sufi brotherhoods in 1925; the adoption of a civil code based on the Swiss model in 1926; the instauration of a new penal code; the adoption of the Latin alphabet and Gregorian calendar in 1928. These institutional reforms were accompanied by others that had profound symbolic significance, relating to clothing (banning of the fez, adoption of the Western suit and hat) and to the patronymic. ${ }^{1}$

1 A 1934 law obliging each citizen to adopt a Turkish patronymic that would be transmitted to descendants. 
During these years the constitution was gradually forged around six concepts, called the "six arrows" (altı ok): the first, in 1927, were "republicanism", "populism", "nationalism", and "secularism"; in 1931, "statism" and "revolution" were added. With the adoption of these principles the nation-state acquired teleological principles that upheld the one-party system and the cult of personality organised around "Atatürk", the father-Turk, a paternal and quasidivine figure who controlled patronymics and (through the calendar) time itself. The republic very quickly constructed and imposed a historical imaginary: the Institute for Turkish History (Türk Tarih Kurumu), created in 1931, built an ideological and messianic national narrative, borrowed in part from the work of Turkey's Orientalists; the reference points for this narrative were pre-Islamic, disavowing any historical links with the Ottoman Empire, which had been roundly rejected by this new state. A reform of universities was launched in 1933, reorganising departments and culminating in an extensive purge of teachers from Ottoman times, and the recruitment in their place of lecturers from Germany who were fleeing the Nazi regime (many of them were Jewish). The subject of theology vanished from universities, and intellectuals and teachers in higher education were invited to work in conformity with the ideology of the single party and with the interests of the Kemalist revolution in mind. The structures of religion were also put under the control of the Turkish state. The religious brotherhoods, powerful structures at the heart of Ottoman society and potentially important conduits for political action, were outlawed in 1925, shutting down an alternative source of power that was not under state control. Turkish secularism means, above all, placing religion under control, rather than just transferring it to the private sphere; the republican project had never explicitly supported the disappearance of religion from the sociopolitical arena. The imposition of the Turkish-language call to prayer in 1936, effective until 1950, is itself a mark of the extent to which religion was nationalised. If historiography, along with the imagery around the history of this reforming Turkish history, heavily underlines the movement for secularisation and laicisation in Kemalist Turkey, the fundamental elements of Islamic doctrine and history were nevertheless taken on by the republican state, and the place of the Prophet in religious teaching in schools constitutes one element in this power dynamic. ${ }^{2}$ It is therefore important to conceive of the status of the person of Muhammad in scholastic programmes not as an element of religious teaching, but rather as a figure who is potentially charged with a republican mission.

2 According to the model of the development of Christianity, put together by Marcel Gauchet, the emphasis on secularisation and laicisation is sometimes wrongly interpreted as a departure from religion. 
Textbooks from the early days of the republic insist on the historicity and rationality of the Prophetic figure, superimposing the republican agenda on Islam and reinterpreting the hadith in a way that justifies the secular republican regime. ${ }^{3}$ Abdülbaki Gölpınarlı (1900-1982), historian of Turkish literature and of Sufi brotherhoods, in a book aimed at schoolchildren and in which the Prophetic figure is presented less as the chosen one receiving revelation and more as a reformer and rational legislator whose aim was to improve the lives of men, was to write: Cumhuriyet devri, hakiki Müslümanlık zamanıdır (The republican era is the era of true Islam) ${ }^{4}$ Numerous texts in this movement insist on the similarities between the figure of the Prophet as representative of true Islam, and that of Atatürk, founder of modern Turkey and successor to the Prophet inasmuch as he protected his people against "hypocritical devotees". Gölpınarl, as an intellectual who was close to Kemalist power, played a major role in unifying Islam and Turkishness in the cultural realm, writing one of the most extensive religious textbooks to be validated by the Ministry of Instruction during 1927-31 for use in primary and village schools. He tells pupils:

The policies of the government of the republic follow the path of the model left by Muhammad ... while dishonest and fanatical hypocritical devotees attempt to prevent the progress of the nation in order to uphold their private and clan interests. Only Mustafa Kemal has succeeded in [following] Muhammad's path. ${ }^{5}$

Apart from his historic role as the founder of Islam, the Prophet is presented as an exceptional moral being who dismantled the caste system and opposed slavery; as for the ümmet, the community of believers, its meaning is constructed around a Prophetic figure who incarnates the high values of political and collective reform. This shifting of the classical reference points of Islam, and the Turkish state's desire to take them over and master them, does not bring about a contestation of the Prophetic figure, but rather its use as a counter-model against religious reaction and superstition, and, along with this,

3 Yusuf Ziya [Yörükan] (1887-1954), a professor in the faculty of theology, was, in the very early days of the republic, the author of textbooks that were used for religious classes in schools: Peygamberimiz (Istanbul, 1926), Din Dersleri: Iman ve İbadet (Istanbul, 1926), İslâm Dini (Istanbul, 1927), Dinimiz (Istanbul, 1929).

4 Muallim Abdülbaki, Cumhuriyet Çocuğunun Din Dersleri, 1929, reissued: Kaynak, Istanbul, 2005,48 .

5 Muallim Abdülbaki, Cumhuriyet Çocuğunun Din Dersleri, 1929, reissued: Kaynak, Istanbul, $2005,5^{0}-51$. 
its increasingly smooth integration into the Turkish national project. ${ }^{6}$ Adapted to the mission and character of the Turkish nation, the life and words of the Prophet become the justification in the profane world for the model rational and moral republican citizen.

\subsection{The Forms of Republican Religious Education}

The young Turkish Republic thus brought an end to the autonomy of institutions of religious education but did not ban religious teaching. This can be observed in the schools that trained imams, imam hatip. In 1913, Ottoman reforms, put into place as part of a new programme (ıslah-i medarir nizamnamesi), brought with them two new schools, the medreset'ül-vaizin and medreset'ül-eimme ve'l-huteba, both intended to train imams and religious cadres. These were combined in 1919 as medresetü'l-irşad. ${ }^{7}$ After the 1924 law of unification of education (tevhid-i tedrisat kanunu) the republic maintained this heritage: schools for imams were controlled by the state, but remained open when the medrese were closed. ${ }^{8}$ However, they appear to have struggled to attract interest, and were closed for lack of students in 1930. This was probably, in part, because of the ambiguous status of these schools as structures for professional religious training and also for general education, and their difficulties reflect the dynamics of the 1930s, a decade that saw the Turkish state increase its control over national cultural references and over all of the contents of education and instruction.

The reopening and increase in numbers, during the 1950s, of schools for imams coincided with the end of single-party rule and the arrival in power of the Democrat Party (Demokrat Partisi), something that had been anticipated at the instigation of a multi-party system in 1946 by the CHP (Cumhuriyet Halk Partisi), some of whose individual deputies proposed initiatives favouring the reintroduction of structures for religious teaching. ${ }^{9}$ In addition, a commission was created by the CHP at this time, motivated in part by its desire to attract the popular conservative vote. ${ }^{10}$ Schools for imams offered four years

$6 \quad$ Numerous texts - which are often hagiographical underneath their historian's clothing underline the recognition of the Prophet's centrality by the chief of the new Turkey: Borak, Atatürkve Din, 17; Karal, Atatürk'ten Düşünceler, 65; Gürtaş, Atatürk ve Din Eğitimi, 38-39. Tekeli and İlkin, Osmanlı İmparatorluğu'nda Ĕgitim ve Bilgi Üretim; Atay, Osmanlılarda Yüksek Din Eğitimi, $308-15$.

8 Ayhan, Türkiye'de Din Eğitimi, 537.

9 Ayhan, Türkiye'de Din Eğitimi, 31-37; Kaymakcan, "Religious Education".

10 Report dating from 10 February 1948, entitled "Din Eğitimi Raporu". 
of training at the primary level, and three years of secondary learning. During the subsequent decades, some of these years of training were passed back and forth between primary and secondary levels; this process brought about major modifications to the length of the training periods. In 1971, the part corresponding to primary teaching disappeared altogether because the schools were professionalised, becoming "Professional Lycées" (meslek liseleri), with a four-year cursus. Changes to the primary level were made in 1973, when a part of this course was transferred to the secondary level, resulting in an increase of the duration of the overall imam hatip training to seven years. In 1997, when eight years of primary education were re-established, the schools for imams were once more limited to the last four years of the secondary-level cursus. ${ }^{11}$ But since 2012-13, when the levels of schooling were restructured to four-plus-fourplus-four years, primary schooling is once more reduced to four years, thus raising the number of years of training in the imam hatip to eight; detractors of this reform argued against this because of the drastic reduction in general teaching for pupils, to four years, after which they were directed towards religious teaching. Despite the fact that these professional schools were formatted and validated by various republican regimes, they did appear to represent a pressure, viewed as being confessional in origin, for an early choice of career.

Faculties of theology faced similar problems and questions during the time of the single party (1923-46). These faculties, which have developed significantly from the 199os onwards, are descendants of the very first department of ulum-i aliye-i diniye (Fundamental Religious Sciences) at the Ottoman University in 1900 (darülfünun-i şahane), which was opened in order to remedy the lack of any higher education in religion. Here the teaching lasted four years and was independent of the medrese; the contents of the curriculum were at first formed from the traditional religious sciences (tefsir-i şerif, hadis-i şerif, usul-i hadis, fikıh, ilm-i kelâm, and tarih-i din-i islam). In 1908, having become ulum-i şeriye, the department added a supplementary series of courses, made up of ilm-i ahlâk-i şer'iye ve tasavvuf (Sufism and religious morality), siyer-i nebevi (Life of the Prophet), and tarih-i edyan (History of religions). Higher education in theology left the university and returned to the ambit of the medrese in 1914, under the name of medresetü'l mütehassisin, and then, in 1918, of süleymaniye medresesi, under the authority of the şeyhülislam. In 1924, the shutting down of the medrese and the reattachment of religious teaching to the authority of the state and the minister of instruction (maarif nezareti) resulted in the creation of a republican faculty of theology, Illahiyat Fakültesi, in parallel with that of

11 Peker, Din ve Ahlâk Ĕ̆itimi, 29. 
the schools for imams; this faculty guaranteed three years of higher education in religion.

As with the schools for imams, the faculty of theology, which had lost a large number of students, closed in 1933; religious higher education was reconfigured in a non-university structure, as İslam İlimleri Tetkik Enstitüsu (Institute of Research into Islamic Knowledge), but this also closed in 1941 for lack of interest and students. Not long after that, during the seventh party congress of the CHP in 1947, during which the question of religious education was debated, the deputy and former minister of education Hamdullah Suphi Tanriöver (1885-1966) used the examples of the Sorbonne, Cambridge, Oxford, and Heidelberg to justify his position in favour of the reintroduction of the teaching of theology. ${ }^{12}$ Affirming that these European institutions were ancient medreses that had then become universities, he underlined the absence of any rupture between the universities' structure and their religious heritage. ${ }^{13}$ Although the congress highlighted the principle of secularism, it associated with it the protection of religion as an aspect of individual liberty and freedom of conscience, guaranteed by the separation of church and state, because of which religion was considered to form a space in which national culture was protected from foreign attack. ${ }^{14}$ This congress provided numerous members of parliament with an opportunity to emphasise (with regret) the marginalisation of the Ministry of Religious Affairs (Diyanet), and to have discussions, based on their own experiences in their respective circumscriptions, about the electoral difficulties brought about when religion was rendered too invisible in the political sphere. To this strategic observation was added an analysis based on a notion of decline in moral values, and on the necessity of offering younger generations a spiritualised citizenship based on their cultural patrimony. Thus, in the various laws and decrees applied during the wave of changes that took place in 1949, the broad formulation of expectations regarding education put the emphasis on national morale, and on each citizen's protection of cultural values (Türk milletin milli, ahlâki, insani, manevi ve kulturel değerlerini benimseyen, koruyan ve geliştiren ... yurttaşlar olarak yetiştirmektir - educating citizens by protecting and developing the national, moral, human, spiritual, and cultural values of Turkish people). ${ }^{15}$

This new dynamic, appropriated by the representatives of a party many members of which had militated for an extensive laicisation (the CHP), came

\footnotetext{
12 See CHP VII. Kurultayı Tutanağı [Report of the CHP's seventh convention], 1948.

13 Hamdullah Suphi Tanriöver, in CHP VII, 455.

14 Ayhan, Türkiye'de Din Eğitimi, g1ff.

15 Framework law no. 1739, Article 2, relating to National Education.
} 
about after the passage into a multi-party system, and during a period when conservative thought (muhafazakâr) was finding a place for itself and the Kemalist revolution was being re-evaluated in milder terms - not as a revolutionary rupture, but as a reformist transition. Religious liberty and morality became favoured themes among magazine chroniclers and writers. Within this framework, the institutional and political contexts of Turkish republican history were associated, and thus determined both the reintroduction of university-level theology and that of religious education in public schools at the primary and secondary levels.

\subsection{Religious Education in Textbooks: The Prophet in the Eventful History of the Din Kültürü ve Ahlâk Bilgisi}

From the time of their creation in 1869, the first Ottoman high schools (sultaniler) provided two hours of religious education each week. ${ }^{16}$ This continued in 1922, and was confirmed by the law of unification in teaching of 1924, as two hours per week of Kur'an-ı Kerim ve Din dersleri at all primary-school levels except for the first year, which was devoted to learning to read and write. In 1926, this was reduced to one hour per week, beginning only from the third year. ${ }^{17}$ In 1931, when schools for imams and faculties of theology were losing numbers and relevance, these courses were completely removed from urban schools; they were cut in village schools in 1939. In 1949, there was an important reconfiguration of the 1924 law of the tevhid-i tedrisat kanunu (Ministry of National Education's communiqué no. 2414), following the extensive parliamentary debates of $1947-49 .{ }^{18}$ Among the results of these debates was a decision to provide optional courses in religion during the fourth and fifth levels of primary education. Linked to the bitter discussions on the necessity for teaching university-level theology, and for a stronger Ministry of Religious Affairs, and situated against the background of the rise of the Democrat Party, this

16 These were created by the 1869 ruling on general instruction (maârif-i mumiye nizamnamesi), which also put into place regulations relative to the Ottoman University, darülfünun.

17 The reference text in this teaching for all three levels concerned between 1927 and $193^{1}$ remained Gölpınarl, Cumhuriyet Cocuğunun Din Dersleri.

18 MEв Tebliğler Dergisi, no. 524, 7 February 1949, 153, http://tebligler.meb.gov.tr/index .php/tuem-sayilar/viewcategory/13-1949. On 6 April 1949, the Turkish government recognised Article 18 (relating to the freedom of conscience and of religion) of the Universal Declaration of Human Rights, as adopted by the United Nations General Assembly: Gürtaş, Atatürk ve Din Eğitimi, 134-35. 
decision relied on assertions that moral values could be inculcated through religious training, and that religion was a foundation of common culture, a social glue, and a tool in the fight against Communism. In 1950, one hour of religious teaching became obligatory (communiqué no. 2949), and in 1957 an option to study religion for an hour per week was offered in the first and second years of secondary school (orta); this was extended to the third year of secondary education in $1976 .{ }^{19}$ In $1982-83$, after the 198 o coup d'état that brutally ended a period of political instability, it became compulsory to study religion for two hours each week at this level; the cursus combined the previous lessons in morality (ahlâk) and in religion (din dersi) under the name Din Kültürü ve Ahlâk Bilgisi (DKAB; Religious and Moral Culture). The semantic and syntactic structure of this title presents religion as an element of culture, and accords a great deal of status to morality (ahlâk) as a transverse phenomenon, at once religious and civic. Referring back to a long tradition of disciplines in religious knowledge, this was also a notion supported by republican thinkers in their debates about secular morality and religious morality (laik ahlâk/dinîahlâk); it allowed them to conceive of a single collective and individual spirituality that involved religion, but went beyond it. Thus, the title of the course expressed in a few words the tense and yet quasi-marital dynamic between religious and republican morality.

A contradiction does appear to come into existence with the creation in 1982 of Article 24 of the Turkish constitution, which affirms both religious freedom and freedom of conscience - this does not sit well with the obligatory and state-controlled nature of religious and moral education. ${ }^{20}$ These circumstances should also be looked at in the light of another state legitimisation of a religious practice, the republican institutionalisation of the cult of the Prophet's birthday (mevlit), the official celebration of which was established in $1989 .{ }^{21}$ Interestingly, since 1994 the dates of these celebrations are no longer aligned with the Hijrī calendar, but with the Gregorian version that was adopted by the republic in 1926. The primacy accorded to republican time in these official commemorations around the Prophet's birth is important.

19 MEв Tebliğler Dergisi, no. 617, 20 November 1950, 116, http://tebligler.meb.gov.tr/index .php/tuem-sayilar/viewcategory/14-1950; Ayhan, Türkiye'de Din Eğitimi, 125.

20 Official text available via: www.mevzuat.gov.tr/MevzuatMetin/1.5.2709.pdf, 136 .

21 Under the name Kutlu Doğum haftası (Holy Week of [the Prophet's] Birth), and in collaboration with the Mevlit Kandili, this week of commemorations between 14 and 20 April was created under pressure from Süleyman Hayri Bolay (b. 1937), a spiritualist intellectual of the 196os who was politically engaged and aimed to consolidate ties between religion and nation. This holy week blends sohbets, ilahi, and conferences, and claims to be founded on scientific bases (ilmî). 
Since the 1990s, the organisation of religious teaching has focused increasingly on a few principal axes, pursuing specific objectives. During the 1980s, these were concentrated around doctrines, rituals, religious morality, and the life of the Prophet (akaid, ibâdet, ahlâk, siyer)..22 Since the end of the 199os, the content of programmes has been evolving regularly: annual communiqués from the Ministry of National Education (Milli Eğitim Bakanlı̆ğ MEB - Tebliğleri) give information about modifications made to programmes, to objectives, and to approved textbook choices.

The importance of compulsory courses in religion has been posited and then confirmed in public education, and implicitly brings with it the necessity for the training of future teachers at the secondary level. Since 1998-99, faculties of theology have been providing a cursus in İlkögretim Din Kültürü ve Ahlâk Bilgisi ögretmenliği (programme of training for teachers of religious and moral culture at the primary level). Since that time, the contents of the cursus and of programmes has been updated regularly. It has been specifically organised around fundamental pedagogical sequences (ünite) that structure and order the contents of teaching and the timescale within which each subject is addressed, in response to precise objectives: in every year, the Prophet features in one sequence. Important changes were put into place in 1992, and again in 2000, in order to help students adapt to new technologies. Within the descriptions of the general principles that guide the pedagogical adjustments affected in the programmes (müfredat) common themes return, such as the importance of cultural patrimony, of good and improved citizenship, and of moral values. From 1982, the idea was to construct a civic morality that conformed to the principles of Atatürk: secularism, national unity, and love of one's neighbour. Among the first sequences put into place at that time can be found "Love for One's Country" (Vatan Sevgisi), "Turks and Islam" (Türkler ve Müslümanlık), and "Secularism and Islam" (Laiklik ve Islamlik). This religious education was intended to offer citizens the tools to participate in a better society, one that was in line with democratic ideals and free of internal contradictions. The combining of courses in morality (compulsory at that time) with the (then optional) courses in religion was another response to the holistic civic approach that had been legitimised by political events around the 12 September 1980 coup d'état, and sanctioned by a fusion between Islam and Turkishness. ${ }^{23}$ The approved textbooks of this period are particularly significant: as early as 1984 , for example, a section entitled "Islam and Turks"

22 As can be observed in the following text, on which much teaching was based: Sâim Kılavuz et al., Din Kültürü ve Ahlâk Bilgisi.

23 Kaymakcan, "Religious Education", 24. 
(İslâmiyet ve Türkler) combines nationalist and religious discourses. ${ }^{24}$ Between 1982 and 1992 these general objectives did not evolve very much. ${ }^{25}$ Within this educational framework, teaching relating to the Prophet was mainly limited to the historic stages of his life (siyer) and his status as messenger, in sequences called Peygamberimiz ve Din (Our Prophet and religion), Peygamberlere inanmak (Believing in the reality of prophets), and Kur'an ve Hz. Muhammed (The Qurān and the Prophet Muhammad). Such teaching was not yet (as it was to become in the 200os) centred around the Prophet's moral and exemplary functions.

\subsection{The Prophet as an Element of Pedagogical, Psychological, and Citizenship Mobilisation}

The reform of educational programmes that took place in 2000 (communiqué no. 2517) relied on much more precise classifications of the areas in which public religious education would have an impact: individual, social, collective, moral, cultural, and universal. Within the "individual" element were numerous subcategories: individual liberty and tolerance in religion; the dimension of love; the necessity of knowing what Islam has in common with other religions; the capacity to distinguish between religious obligations and cultural habits (örf ve adetler); the ability to differentiate between true religion and superstition; an awareness of the conformity of Islam with science; the importance of being at peace with one's own religion. The emphasis is put on the resolution of an individual's internal and psychological conflicts, as well as of conflicts between the individual and religion, family or social conflicts, and those relating to religion's compatibility with logic and science.

The collective issues identified by these new programmes relate to the importance of familiarity with collective religious rituals and behaviours, and to interreligious tolerance, protection of the environment, and the ways in which social habits may influence religious beliefs. The moral issues at stake have to do with the interiorisation of moral values, and with an awareness of the value of faith and rituals. Finally, this programme identifies cultural issues, such as the capacity to identify the role of religion within the emergence and development of a culture, and the development of a peaceful approach to generational differences. Here again, one can observe the emphasis laid on the supposed benefits brought by scholastically acquired religious culture; for

24 In, for example, Sâim Kılavuz et al., Din Kültürü ve Ahlâk Bilgisi, 699ff.

25 Kurt, "1982, 1992 ve 200o", 131. 
example, in the resolution of conflict. Finally, the more general issues at stake relate to the capacity to appreciate the universal values of religious conscience and knowledge, and to approach other religions with understanding and tolerance (and on the basis of at least a minimal understanding of their principal specificities). Additionally, the accent placed on the correspondences between Islam and secular, modern, universal values is an important particular in the renewal of these programmes.

The main difference between the programmes of 1982 and 2000 is that the former underlines the contributions of its cursus to historical knowledge and doctrinal mastery and, separately, its support for civic awareness; the latter course of study brings these two dimensions together, justifying them and expanding the scope of the programme, which is presented in terms of psychology, interpersonal relations, and social and pragmatic interests. Within this framework, and in parallel with the continuing importance of the Prophet's life in these courses, the increasing emphasis on his status as an individual, familial, social, and civic model acquires a new relevance. This is a body of acquired education conceived as knowledge applicable to contemporary issues and conforming to contemporary standards around behaviour and social administration; its elaboration was accompanied by the development in Turkey of a cognitive and constructivist pedagogy. In both programmes, the "formatting" of the citizen is fundamental; this follows the path laid out since the very beginning of the republican era, along which there may have been diverse approaches to questions of citizenship and identity, but always with an eye to maintaining the emphasis on civic loyalty, and the correspondence between Islam and the interests of the state. When one looks closely at the developments in the DKAB course, it appears increasingly as an emanation of a problem set by the state: that of the social individual interacting with society as a whole, with the political arena, and with Turkishness. In addition to cognitive and pragmatic approaches to religious instruction, the 2000 reform also adds transnational and universal questions to which religious culture is expected to find answers, along with a new willingness to interact and compare with, or measure up to, religious teaching in Europe.

Specifically, the emphasis is here placed on the balance and health of the individual (in body, soul, cleanliness, morality, intelligence, and cultural protection), in terms of "benefits of religion for personal development", of the capacity to "adapt oneself to the religious dimension of social existence", "choosing between justified and false attitudes", "conceptualising the universal dimension of religion", "ridding oneself of politico-religious groups [sects], distancing oneself from them, being able to identify real religion, and avoiding superstition", "being able to understand the cultural dimension of religion 
and interiorise it in order to improve it", and, finally, "identifying religious principles in individual and collective moral attitudes". One of the important particularities of the programmes in 2000, as compared with the first pedagogical programmes of 1949, lies in the addition of Toplumsal Görevlerimiz ve Din (Our social duties and religion): ${ }^{26}$ this formulation clearly underlines the fact that religion is not treated as an end in itself, but as a tool and condition for the improvement of the nation's social organisation.

An important indicator of the increasing space accorded to the figure of the Prophet is the appearance in 2000 of a sequence to be used in the final year of primary school, devoted to "The Prophet Muhammad and Family Life" (Hz. Muhammed ve aile hayatı), which was not in the programmes from 1949 to 1992, but has been maintained permanently since 2000 (it is included in the programmes of 2010 and 2018). ${ }^{27}$ Here it is the human and social dimensions of the Prophet that are discussed, notably his qualities as a father and husband: he is gifted with perfect moral qualities (merhamet, sabır, şükr, beraberlik: mercy, patience, gratitude, sociability). He is also a good relative and neighbour, acting justly towards all people, loving his neighbour, and offering assistance with domestic tasks. One of the new functions of the sequence was to legitimise commemorations and devotional practices around the birth of the Prophet (mevlit):

Finally, it is right to remember the importance of the Prophet's birth with regard to what he brought to humanity, and therefore right to justify its celebration (mevlit kutlamaları) as an occasion to know him better and to put into practice his fine example (socialisation, visits to family, help for the poor and wretched). ${ }^{28}$

Elsewhere, the programme for the first year of middle school provides for a unit called "Muhammad, the Last Prophet" (Son Peygamber Hz. Muhammed), within which the pacifying nature and social function of the Prophet are underlined on the basis of biographical elements. However, with the programmes of 2000 it is especially at level eight (third year of middle school) that the figure of the Prophet acquires a radical and transversal dimension as an exemplar: the year's first sequence is called "The Exemplary Morality of Muhammad"

26 MEB Tebliğler Dergisi, no. 2517, October 200o, and $M E B$ Tebliğler Dergisi, no. 936, December 1956.

27 MEв Tebliğler Dergisi, no. 937, December 1956; Acar, “Ilkoğretim 4. ve 5.”, 73.

$28 \quad$ мев Tebliğler Dergisi, no. 932, December 1956. 
(Hz. Muhammed'in Örnek Ahlâk); it highlights the Prophet's social and interactional qualities, and his reliability as a model.

If the elements of mastery and doctrine in the teachings of Islam were preeminent in the textbooks of the 1980 s, from 2000 these began to disappear as the content of teaching was constructed and placed in the curriculum because of its function in the day-to-day life (social, familial, civic) of the student learner. This point can be related to concomitant developments in pedagogy, and to the increasingly detailed specifications for learning at each level, as the programmes were becoming more and more extensive. The Prophet's importance acquired a particular dimension when looked at from a constructivist (yapılandırmacı) perspective; this approach gradually came to be preferred by pedagogues in faculties of theology, and modified the preferred outlook of earlier educators, which was a more behaviourist (davranış̧ı) pedagogy, undertaken according to objectives and via conditioning. It is interesting to observe the extent to which religion, which could itself be treated as an issue of mastery and doctrine, is instead imbued with and upheld not only by patriotic and republican ideology, but by deep pedagogical reflection claiming to be centred around the idea of an active learner (ögrenci merkezli) and founded on the conceptualisation arrived at by the student her- or himself on the basis of the problems that are addressed and discussed. These various pedagogical options make sense when looked at in the light of the history of Turkish republican education, which, from the beginning, was undertaken from the point of view of developments in pedagogy as a science. ${ }^{29}$ The pedagogical models and theories used were very much founded on the work of Jean Piaget and John Dewey, and, more recently, on the works of Michael Grimmitt, who proposes a distinction between "learning religion" (din hakkında ögrenmek), "learning about religion" (din hakkında öğrenmek), and "learning from religion" (dinden ögrenmek); ${ }^{30}$ these distinctions allow him to dissociate public education in religion from ultra-confessional religious instruction. ${ }^{31}$ Since the 2000 , numerous pedagogues and actors within faculties of theology conceive of the DKAB teaching as progressive, structured with specific objectives and stages in mind, and taking into account the personal, different, and relative nature of the individual faced with knowledge and learning. Here learning is intended to occur as autonomous research into solutions to problems (sorun merkezli)

29 The theories of John Dewey and Jean Piaget had an impact from the beginnings of the republic; Dewey was consulted in 1924 to provide expertise in the construction of the new Turkey's education system: Sarmis, "Psychologies ottomanes et turques (186o-1930)".

30 Mentioned by Ev, Din Kültürü ve Ahlak Bilgisi Derslerinde Probleme, 57-58.

31 Grimmitt, What Can I Do in RE?; Grimmitt, "Constructivist Pedagogies". 
undertaken by the learner, who is placed in a situation of cognitive conflict that the discipline of DКАв appears particularly to incarnate. The defenders of this approach admit that there are risks attached to imposing this cognitive conflict on students, because it may carry with it the invitation to look critically at religious dogmas, but they argue that the globalised context and plural nature of Turkish society require the teaching of religion to be opened up to such pedagogical options. ${ }^{32}$ This approach, springing from an inclusive and pragmatic pedagogy, also favours the emergence of the Prophet as an absolute moral example. For most ordinary students, the biographical examples and hadiths about the Prophet's excellent moral conduct favour their interiorisation of the Prophet's example, and rather than embodying inaccessible perfection, he nevertheless remains eminently accessible, because he is human. We also observe that the term siyer, which was still used in the 1980s to refer to the part of religious teaching devoted to the Prophet, has completely disappeared as a category of knowledge, now indicating simply sources of information about the Prophet.

During the 200os, after the negotiations about Turkey becoming part of the European Union, working groups were organised around the reform of school programmes. ${ }^{33}$ The result of these was a series of reflections on the role of the teaching of religion in relation to social and communitarian cohesion, and to citizenship. Religion was not perceived as an isolated system of doctrines and values, but as a psychological and social resource. In opposition to the pedagogical paradigm based on the transmission and assimilation of known facts, this approach favours an education that integrates knowledge in a way that is coherent in the context and environment of the student, who, through the adjustments made necessary by cognitive conflict, becomes an actor in her or his own vision of the world and of interactions. These working groups also examined the ways in which European countries teach religion, and their work and research culminated in the organisation of a major symposium in $2001 .^{34}$ This was succeeded by a series of experiments at the faculty of theology of the Dokuz Eylül University, examining a constructivist style of pedagogy under the overall title of "active education" (aktif eğitim); this was then used in educational programmes. This modified the behaviourist approach that had already been adopted in earlier versions of the programme, aiming above all to spread pedagogical practices that put the learner into a confrontation with the real

32 Ev, Din Kültürü ve Ahlak Bilgisi Derslerinde Probleme, 6o.

33 Ev, Din Kültürü ve Ahlak Bilgisi Derslerinde Probleme, 31.

34 Avrupa Birliğine Giriş Sürecinde Türkiye'de Din Eğitimi ve Sorunları Sempozyumu, Adapazarı, 26-27 May 2001; reports appeared in 2002. 
effects of religious knowledge, both on the construction of the individual and on social and collective interactions.

In recent programmes, the DКАВ course for middle school years 4 to 8 is constructed and organised around five sequences; as well as one providing general knowledge of Islam, and another focussing on the rituals and pillars of Islam and its social value, there is a sequence devoted specifically to the Prophet, which aims to teach the life of the Prophet and present it as a moral model (örnek ahlâk, exemplary morality). Reminders of his historic role in the propagation of Islam are accompanied by an emphasis on his exemplary nature: at this level nothing is taught about the particularities of his theological status. Thus, the programme puts the emphasis on social equality and the struggles against division and injustices founded on race, and even on gender - injustices that the Prophet is reputed to have abolished. The 2018 programmes, which modify those of 2010, offer, in the fourth sequence devoted to the Prophet, Hz. Muhammed'i Taniyalım (Let's get to know Muhammad, level 4), Hz. Muhammed ve Aile Hayatı (The Prophet and family life, level 5), Hz. Muhammed'in Hayatı (The life of the Prophet, level 6), Allah'in Kulu ve Elçisi: Hz. Muhammed (The servant and messenger of Allah, level 7), and $\mathrm{Hz}$. Muhammed'in Örnekliği (Muḥammad as exemplar, level 8). Little has changed since 2010, but we do note the addition of verses and prayers that must be learned by the end of each sub-sequence.

At the high school level (years 9-12), the moral and ethical dimension is treated as part of the general message of Islam itself, and not only as part of the message brought by the Prophet. Level 10 also incorporates a group of lessons called Hz. Muhammed ve gençlik (The Prophet and young people), using sūra 3 (Āl Imrān), especially its verse 159; the aim of these lessons is to speak directly to the generation studying them. During 2018-19, the moral content has been expanded at the expense of biographical detail: mercy, patience, gratitude, solidarity (merhamet, sabir, şükr, beraberlik). The Prophet's status as moral exemplar takes its place in a fairly extensive range of teaching: Judaism and Christianity are discussed in the final sequence of level 11; level 12 also includes teaching on contemporary religious problems (including medical ethics), Islam in Anatolia, the links between Islam and science, Islamic mysticism (tasavvuf, including Alevism and Bektashism, cults and rituals), and, finally, the religions of India and the Far East. ${ }^{35}$

Overall, the double nature of Muhammad is always accentuated: he is human, and he is also a Prophet. His status as a model is underlined; the programmes demand thorough knowledge of the Prophet's life, which is

Official programmes available via: https ://bit.ly/2SdWQh7. 
approached in a progressive but slightly fragmented way by comparison with the didactic blocks that made up the larger part of 1980 os textbooks. ${ }^{36}$ The lessons in later textbooks are based on precise examples, portraying very general virtue and making the Prophet into the ideal model of an individual, a father, a spouse, and a citizen. In this respect, what is considered important is not the ontological status of the Prophet, but his status as a model. ${ }^{37}$ The tension visible in these programmes, between factual and doctrinal history, on the one hand, and the pedagogical and psychological structures built around the Prophet as model, on the other, upholds the notion of a pedagogical "return" to the political centrality of the Prophet; in our terms, the exploitation, in dedicated lessons, of the Prophetic model to construct an ideal model citizen is made easier through the use of recent teaching practices of the constructivist type. This pedagogical option allows for the diminishing of any conflict, or even competition, between religious doctrine and the republican environment.

\subsection{Is Learning about the Prophet in Turkish National Education Becoming Autonomous?}

Alongside the greater number of religious lessons devoted to the figure of the Prophet in Turkish public education since the beginning of the century, history classes at the secondary level (starting in year 9) contain a sequence called İslâm Tarihi ve Uygarlığı (Islamic history and civilisation), including İslâmiyet'in doğuşu ve Hz. Muhammed Dönemi (The birth of Islam and times of the Prophet Muhammad). Since 2017, an additional class devoted entirely to the Prophet (in parallel with the DКА courses in religious and moral culture) has been added to the four-plus-four-plus-four system that was put into place in 2012. In the Imam Hatip this (obligatory) course is called Siyer dersi, and in the general education system it is optional, under the name Hz. Muhammed'in Hayatı or Peygamberimizin hayatı (Life of the Prophet Muhammad or Life of our Prophet). ${ }^{38}$ Initially offered at levels 5 and 9 (respectively the first year of middle and of high school), it is now being extended throughout the secondary school programme. Conforming to the above-mentioned tendency to support constructivist theories, official programmes mention among the

\footnotetext{
${ }_{3} 6$ Sâim Kılavuz et al., Din Kültürü ve Ahlâk Bilgisi, $571 \mathrm{ff}$.

37 This was already present in the above-cited textbook from 1985: Sâim Kılavuz et al., Din Kültürü ve Ahlâk Bilgisi, 159 and 397, in the "Morality" section.

38 Köse, "Milli Eğitim Bakanlığı Tarafından Hazırlanan Peybamberimizin Hayatı ve Siyer", $108-9$.
} 
principles guiding their construction of pedagogical activities the aims of "learning to learn" (Öğrenmeyi ögrenme), the development of autonomy and initiative (Inisiyatif alma ve girişimcilik), and the inclusion of activities connected with citizenship and social existence (Sosyal ve vatandaşlıkla ilgili yetkinlikler). ${ }^{39}$

During the first cycle (primary and middle school levels), this course has several fundamental objectives: ${ }^{40}$ to explain the notion of a prophet, as well as the particularities of the different prophets (kavramını ve peygamberlerin özelliklerini açılaması); to learn about the environment into which the Prophet was born (Peygamberimizin doğduğu çevrenin genel özelliklerini tanıması); to be able to distinguish between his human and prophetic characteristics (Peygamberimizin beşerî ve nebevi yönlerini fark etmesi); to understand the Prophetic model in its individual and its collective aspects (Peygamberimizin örnek kişiliğini bireysel ve toplumsal açılardan kavraması); to love the Prophet and follow his example (Peygamberimizi severek kendisine örnek alması); to understand the notions of sahaba (the Prophet's companions) and their exemplary nature (Sahabi kavramını ve sahabenin örnekliğini kavraması); to identify manifestations of love for the Prophet in our culture and civilisation (Kültür ve medeniyetimizdeki peygamber sevgisinin tezahürlerini fark etmesi); and to have a holistic understanding of our Prophet's life (Peygamberimizin hayatın bütüncül bir yaklaşımla tanıması). Mostly based on the hadïth, the Sosyal hayatta peygamberimiz and Peygamberimizin Örnekliği sequences are conceived to support the interiorisation and evident nature of the Prophetic model, according to a pedagogical logic that legitimises his centrality on psychological, social, and rational grounds.

We observe that recent programmes at the high school level (years 9-12) claim that the learning in primary and middle schools aims to result in:41 "the interiorisation [by the pupils] of national and spiritual values, and their transformation into a way of life, that they may contribute as active and productive citizens to the economic, social and cultural development of our country". ${ }^{2}$ One major evolution that now takes place as pupils progress from

39 Page 4 of the official programmes of 2018. The contents of these programmes are available on the official website of the Ministry of National Education: https ://ogm.meb.gov.tr/ www/icerik_goruntule.php ?KNO=14.

$40 \quad$ For 2018, see page 9 of the programmes cited above.

41 Accessible here: https ://bit.ly/3gRUgHw.

42 "Liseyi tamamlayan öğrencilerin, ilkokulda ve ortaokulda kazandıkları yetkinlikleri geliştirmek suretiyle, millî ve manevi değerleri benimseyip hayat tarzına dönüştürmüş, üretken ve aktif vatandaşlar olarak yurdumuzun iktisadi, sosyal ve kültürel kalkınmasına katkıda bulunan," page 1 of the official programmes for 2018. 
year 9 through to year 12 thus consists in the passage from general study of the Prophet's life and his importance as example and model, along with study of his many significant roles in Islam (educator, messenger, social reformer, master of warfare), to the study of his role in Turkish social and cultural transitions (Kültürümüzde Peygamberimiz); this is a new approach when compared with the DKAB sequences devoted to the Prophet: the Prophet is now presented as a third party and intermediary, allowing one to conceptualise Turkish history and the country's contemporary problems. A pragmatic way of interpreting hadith is preferred: from year 2 the sub-sequences accentuate knowledge of the hadith and their sources, and ways of using them to interpret contemporary life and its specific problems (Hadis'ten Hayata, from hadith to life). From this point of view, this course (to date an optional one) is more developed and explicit than the compulsory course that is part of the DКАВ. Like the latter, it is supposed to pursue the generic moral objectives of public education ("justice, friendship, honesty, self-mastery, patience, respect, love, responsibility, love for one's nation, altruism"). The writings of the theologian Muhammad Hamidullah (1908-2002), who worked as an academic in Turkey for a few years, played an important role in the development of these courses. ${ }^{43}$

Although this cursus proposes a return to the centrality of the Prophet without competing with republican principles, it nevertheless makes some contribution to increasing the autonomy of the discipline of the study of the Prophet. The visibility of the Prophet in these new teaching programmes goes along with a movement to institutionalise research into the life (sira) of the Prophet. Interestingly, the return to a form of historical and doctrinal accuracy in the treatment of the figure of the Prophet (through courses focussing on his sira) brings about a personal investment, on the part of theologians, in this didactic approach, and thus blurs the lines between public education, controlled by the Ministry of National Education (МЕв), and religious teaching, controlled by the Ministry of Religious Affairs. The textbooks introduced in 2017 for this course have been widely criticised for lacking precision as to the specificities of the sira/siyer genre, as based on a branch of Islamic

43 Muhammad Hamidullah, an important reference point for theology in Turkish universities, was an Indian scholar and university lecturer with degrees in philosophy and literature. Specialising in Muslim jurisprudence and the science of hadith, in 1947 he contributed to the composition of the constitution of Pakistan. He translated the Qurān into French (Le Saint Coran: traduction et commentaire de Muhammad Hamidullah avec la collaboration de M. Leturmy, 1959), wrote a biography of the Prophet Muhammad (Le Prophète de l'Islam, sa vie, son œuvre, 2 vols, 2001), and his work has been translated into many languages; he held a number of university posts in Turkey, and especially, from 1954, at the CNRS in France. 
knowledge: ${ }^{44}$ these criticisms occur in the context of an increased interest at universities in the sira of the Prophet, which has led to a flourishing literature on the subject, to the organisation of a major scientific congress in 2010, and to workshops (Siyer Öğretimi Çalsştayları) on the teaching of the sira of the Prophet, organised between 2015 and $2018 .{ }^{45}$ Public education, by including specific disciplinary learning goals on the Prophet, finds itself in a position in which representatives of the norms of doctrinal and religious science have a stake, and opens itself to criticisms that were more easily resisted by the DKAB because of its very strong civic and moral dimension.

\subsection{Conclusion: Teaching the Figure of the Prophet - A Tool for the Modern Turkish State as It Evolves}

The study of courses on religion in Turkish national education is particularly interesting because the subject engages with a fundamental and emblematic tension that has existed throughout the history of education in republican Turkey. This chapter sought to clarify the role taken on by the figure of the Prophet in a secularised country where the teaching of religion is not based on strict religious instruction. The involvement of public and state institutions in this teaching brings many factors into play, the effect of which is to associate the learning of civic virtues with that of religious culture.

As these courses have evolved since 1949, they have become increasingly structured and the framing of lessons more detailed (sequences, themes, objectives, knowledge to be acquired, sources such as specific hadiths and Qur'ānic verses). Sequences on the Prophet were still a single block in 1984; since 2000 these have spread across several areas of study (life, double nature as human and divine, moral example, the good man, usefulness to the nation, usefulness for Turkishness), giving way to an intention for learning to be more interactive and progressive. This is now complemented by a course on the Prophet introduced in 2017 (and still, for the moment, optional); in this the central figure of Islam becomes the pivot of learning about religion, and of learning to apply religion. This allows the appropriation and the embodiment of religious knowledge through an identification object that appears to

44 For the textbooks, see those of Pütkül and Vasif Körpe, Peygamberimizin Hayatl; Akkaya et al., Peygamberimizin Hayatı; Köse, "Milli Eğitim Bakanlığı Tarafından Hazırlanan Peybamberimizin Hayatı ve Siyer".

Türkiye'de Siret Yazıclığı Sempozyumu-I, Istanbul, 16-17 October 2010; reports published in 2012 in Ankara. In 2016, the magazine Siyer Araştırmaları Dergisi was also released (first issue appeared 2017) under the auspices of a foundation for the sira (Siyer Vakfi, founded by Muhammed Emin Yıldırım). 
function efficiently alongside the constructivist developments favoured by some Turkish pedagogues. The importance of the Prophet in these lessons and textbooks is also part of a more general phenomenon visible since the 1980s, when these courses became obligatory: for instance, the appearance of commemorations and of the ritual of the kutlu doğum (the holy birth of the Prophet), and the development of a sira literature linked to the literature of mutual aid. Here, the figure of the Prophet nourishes aspirations that may be communitarian or individualist, such as the notion of finding within oneself the tools for salvation. In effect, the figure of the Prophet sets up a stall in the psycho-spiritual marketplace of contemporary Turkey; another manifestation of this is the renewal of Prophetic medicine, tıbb-i nebevi, which the Ministry of Health has recognised as a gentle alternative form of health care.

Since its beginnings, the DKAB has been a politically and civically engaged form of teaching: transversally constructed with a view to reinforcing national feeling, it exists at the crossroads between social morality and religious knowledge. In this programme, the Prophet is presented less as an absolute authority than as a model for the individual who is supposed to adapt to her or his environment and reach an increasingly pure moral state. The figure of the Prophet functions to make society more cohesive; it is in line with the democratic project, and this is underlined. Muhammad is presented as the exemplar of the ideal citizen who experiences no contradictions within his environment (in any domain of human interactions - familial, economic, state-related). As discussed at length in the principles that guided the reform of 2000, the main psychological objective for these teaching methods is to arrange individual differences within the collective experience without causing contradictions to emerge. Thus, they become a tool for the civic education of citizens, and the model of the Prophet is a way of digging down to the very roots of Turkish citizenship. The Prophet's religious sacredness here serves a civic pragmatism; Muhammad is exceptional because of his extreme accessibility, highlighted through universal and up-to-date examples that encourage identification and can be appropriated by any student. He is a pacifying figure, protecting against sectarian detours and compatible with the republican and democratic context. The potency of this Prophetic figure as one with which people may identify despite the fact that, in the 1930 s and 1940s, works dedicated to him risked being banned - is in direct correlation, in the context of Turkish public education, with the neutralisation of his exclusivity and his political centrality. ${ }^{46}$

46 For instance, a book on the Prophet, forbidden by the Kemalist regime in 1938, was written by Ömer Rıza Doğrul (1893-1952), the author of several books on Islam and the Muslim world, and also translator of the Qurān. 


\section{Bibliography}

\section{Primary Sources}

CHP VII. Kurultayı Tutanağı, Ankara, Ulus Basımevi, 1948.

Gölpınarlı. A. Cumhuriyet Cocuğunun Din Dersleri, Istanbul, Tefeyyüz Kitaphanesi, 1927-31.

Karal, E. Z. Atatürk'ten Düşünceler, Ankara, Türkiye İş Bankası Kültür Yayınları, 1969.

Kurt, F. "1982, 1992 ve 2000, İlköğretim Okulları Din Kültürü ve Ahlâk Bilgisi Dersi Müfredatlarının Mukayesesi", master's thesis, University of Marmara, 2002.

мев Tebliğler Dergisi, http://tebligler.meb.gov.tr/index.php/tuem-sayilar/viewcate gory/64-20oo.

\section{Secondary Literature}

Acar, A. "İlkoğretim 4. ve 5. inci Sınıf Din Kültürü ve Ahlâk Bilgisi Öğretimi Dersi Müfredatlarının Mukayesesi", PhD diss., University of Marmara, 2006.

Akkaya, V. S., M. Âdem-Durak, and N. Berat-Akkaya. Peygamberimizin Hayatı-Ortaokul ve Imam Hatip Ortaokulu 5. Sinıf-, Ankara, м в в Yayınları, 2017.

Atay, H. Osmanlılarda Yüksek Din Eğitimi. Medrese Programları, İcazetnâmeler, Islahat Hareketleri, Istanbul, Dergâh yayınlanı, 1983 .

Ayhan, H. Türkiye'de Din Eğitimi (1920-1998), Istanbul, M.Ü. İlâhiyat Fakültesi Vakfı Yayınları, 1999.

Borak, S. Atatürk ve Din, Istanbul, Anıl Yayınevi, 1962.

Ev, H. Din Kültürü ve Ahlâk Bilgisi Derslerinde Probleme Dayalı Öğrenme, Ankara, Nobel Yayınları, 2012.

Grimmitt, M. What Can I Do in RE?, Great Wakering, Mayhew-McCrimmon, 1973.

Grimmitt, M. "Constructivist Pedagogies of Religious Education Project: Re-thinking Knowledge, Teaching and Learning in Religious Education", in M. Grimmitt, ed., Pedagogies of Religious Education, Great Wakering, Mayhew-McCrimmon, 200o, 189-207.

Gürtaş, A. Atatürk ve Din Eğitimi, Ankara, Diyanet Işleri Bakanlığı Yayınları, 1981.

Kaymakcan, R. "Religious Education in the Multi-party Period in Turkey", East/West Education 17/1-2 (1996), 91-107.

Köse, F. B. "Milli Eğitim Bakanlığı Tarafından Hazırlanan Peybamberimizin Hayatı ve Siyer Ders Kitaplarının Tahlil ve Tenkidi", Siyer Araştrmaları Dergisi 3 (JanuaryJune 2018), 107-40.

Peker, H. Din ve Ahlâk Eğitimi, Samsun, Aksi Seda Matbaası, 1998.

Pütkül, H. Z., and M. Vasif Körpe. Peygamberimizin Hayatı - Ortaöğretim 9. Sinıf, Ankara, м в в Yayınları, 2017. 
Sâim Kılavuz, A., et al. Din Kültürü ve Ahlâk Bilgisi. Kaynak Kitap, Istanbul, Marifet Yayınları, 1984.

Sarmis, D. "Psychologies ottomanes et turques (186o-1930). Un laboratoire pour les partages savants", Revue d'histoire des sciences humaines 34 (2019), 35-66.

Tekeli, İ., and S. İlkin. Osmanlı İmparatorluğu'nda Eğitim ve Bilgi Üretim Sisteminin Oluşumu ve Dönüşümü, Ankara, Türk Tarih Kurumu Basımevi, 1993. 